ISSN (Print) : :1412-7601

ISSN (Online) : 2654-8712

Volume 7, No.1 Maret 2021

EKONOBIS

http://www.ekonobis.unram.ac.id

\title{
TATA KELOLA REMITANSI BURUH MIGRAN: KASUS BURUH MIGRAN DI KABUPATEN LOMBOK TIMUR
}

\section{Jalaludin.}

Universitas Mataram ARTICLE INFO

Keywords:

management, workers remittance, migrant

ABSTRACT : Migrant workers have a major contribution to economic and welfare development through remittances sent to their places of origin. The remittances will raise the economic status of the migrant family with proper management. This study aims to determine the remittances management of migrant laborers in the East Lombok district. This study used a qualitative approach by applying several data collection methods, namely Observation, In-depth Interview, and Focus Group Discussion (FGD). Data analysis was performed in a qualitative descriptive manner based. Some of the points found were: a safe and cheap mechanism for sending remittances is still needed, more expenses for consumption needs, capacity building is necessary to assist BMIs to start a business, and strongly patriarchal culture in the use of remittances that come from female migrant workers.

Kata Kunci: tata kelola, remitansi, buruh migran
ABSTRAK: Buruh migran memiliki sumbangan yang besar dalam pembangunan ekonomi dan peningkatan kesejahteraan melalui remitan yang dikirim ke daerah asal. Remitan yang dikirimkan ke daerah asal akan mampu mengangkat status ekonomi keluarga migran ke tingkat yang lebih baik apabila dikelola dengan baik. Kajian ini bertujuan untuk mengetahui tatakelola/ pengelolaan remitansi buruh migrani di kabupaten Lombok Timur. Metode atau pendekatan penelitian yang digunakan adalah pendekatan kualitatif dengan menerapkan beberapa metode pengambilan data yaitu Observasi/Pengamatan, Indepth Interview dan Focus Group Discussion (FGD). Sementara analisis data dilakukan secara dekriftif kualitatif berdasarkan data atau informasi lapangan. Beberapa point yang ditemukan dalam penelitian ini adalah ; masih diperlukannya mekanisme pengiriman remitansi yang aman dan murah, remitansi masih lebih digunakan untuk kebutuhan konsumsi, diperlukannya capacity building untuk membantu BMI memulai usaha, masih kentalnya budaya patriarki dalam pemanfaatan remitansi yang datang dari buruh migran perempuan.

Corresponding Author :

Alamat : Program Studi Ekonomi Pembangunan, Fakultas Ekonomi dan Bisnis, Universitas Mataram, Jln. Majapahit No. 62 Mataram.

e-mail: jalaludin@unram.ac.id 


\section{PENDAHULUAN}

Jumlah dan pertumbuhan penduduk yang tinggi bisa berdampak positif, yaitu dapat meningkatkan jumlah tenaga kerja yang tersedia yang menjadi unsur penting dalam eningkatkan produksi dan mengembangkan kegiatan ekonomi. Namun jika lapangan pekerjaan yang tersedia tidak cukup menampung jumlah tenaga kerja yang ada maka hal ini justru akan berdampak pada meningkatnya angka pengangguran yang pada gilirannya akan meningkatkan angka kemiskinan. Dalam konteks inilah, migrasi penduduk ke luar negeri menjadi buruh migran menjadi suatu alternatif yang tak terelakkan. Selain minimnya lapangan pekerjaan yang tersedia di dalam negeri atau daerah, perbedaan pendapatan antar daerah maupun antar negara yang sangat mencolok antara negara miskin, negara berkembang dengan negara-negara maju juga menjadi alasan utama menjadi buruh migran.

Dalam konteks pembangunan ekonomi, sumbangan migran memiliki pengaruh cukup besar terutama dalam meningkatkan kesejahteraan penduduk. Remitan yang dikirimkan migran ke daerah asalnya telah mampu mengangkat status ekonomi keluarga migran ke tingkat yang lebih baik. Hal tersebut menunjukkan bahwa, tingginya arus migrasi dari dan ke suatu wilayah tertentu menjadi faktor penting yang mempercepat terjadinya proses transformasi sosial kultural. Dengan demikian, aktivitas migrasi terjadi atau berlangsung dalam kondisi ekonomi yang dinamis, melebur ke dalam konteks arus migrasi kapital. Dalam konteks lebih luas aliran tenaga kerja yang berlangsung secara universal harus dilihat di dalam kerangka investasi ekonomi. Realitas migrasi global merupakan aktivitas yang berlangsung dalam konteks ekonomi produktif yang memberikan kontribusi besar dalam proses pembangunan ekonomi. Hal ini sekaligus juga menepatkan remitansi buruh migran yang begitu besar yang mengalir antar negara merupakan persoalan penting yang harus dikelola agar bisa bermanfaat maksimal bukan saja pada pelaku migran (keluarga) tapi juga untuk peningkatan ekonomi di daerah asal buruh migran

Berdasarkan data Migration and Remittances Factbook 2016 (Third Edition) yang dikeluarkan oleh World Bank Group menggambarkan besarnya arus remitansi yang mengalir melewati batas negaranegara dan kawasan di dunia. Dari data yang berhasil mereka kumpulkan dari publikasi resmi tentang remitansi, pada 
2015, arus remitansi di seluruh dunia mencapai lebih dari 601 miliar dollar AS (World Bank Group, 2016). Dari keseluruhan jumlah tersebut, sekitar 441 miliar dolar AS diterima oleh negaranegara berkembang yang merupakan hampir tiga kali jumlah bantuan pembangunan. Perludigarisbawahi bahwa data-data yang umumnya dikumpulkan dan dipublikasikan ini seringkali tidak mencakup dana-dana yang tidak tercatat yang ditransfer melalui jalur formal dan informal.

Jumlah remintasi buruh migran yang mengalir lintas negara terus mengalami peningkatan setiap tahun. Berdasarkan data Bank Indonesia, remitansi atau kiriman devisa dari pekerja migran
Indonesia yang mengadu nasib di luar negeri sepanjang kuartal II-2020 mencapai US\$ 2.262 juta atau setara Rp 33,4 triliun (kurs Rp 14.744). Nilai tersebut turun 13\% dibandingkan kuartal I-2020. Menurut sumber atau negara asal negara remitansi, Arab Saudi tercatat menyumbang remitansi terbesar yakni mencapai US\$ 713 juta. Kemudian, diikuti oleh Malaysia, Taiwan, Hong Kong, dan Singapura. (Bank Indonesia, Kata data, 2020). Hal ini menunjukkan bahwa, wilayah Timur Tengah merupakan penyumbang remitansi paling besar dibandingkan wilayah Asia Tenggara, Asia, Australia, Afrika, Amerika, dan Eropa. Nilainya yakni mencapai US\$ 809 juta.

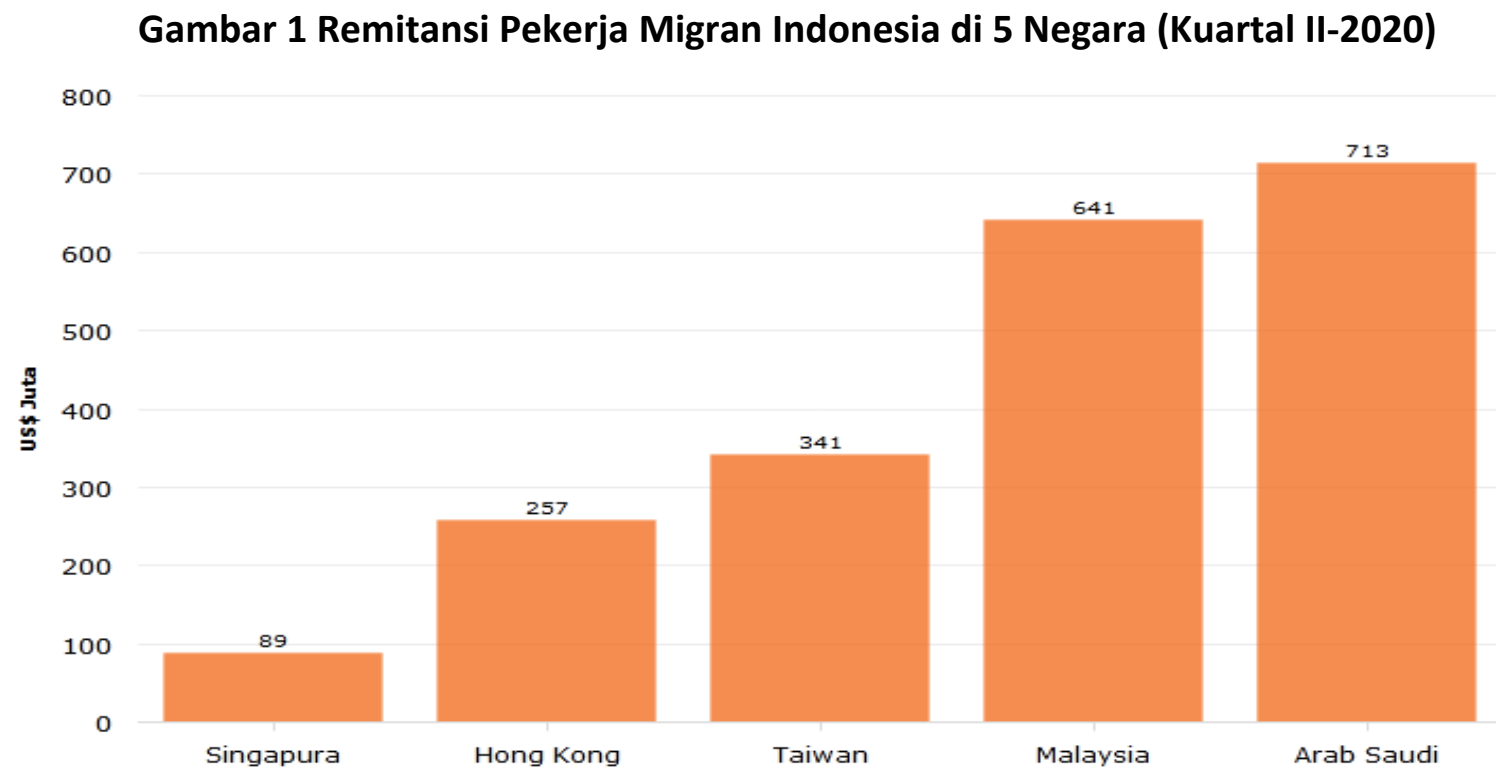


Provinsi Nusa Tenggara Barat (NTB) merupakan salah satu kantong Pekerja Migran Indonesia (PMI). Dengan jumlah penempatan yang cukup signifikan dan remitansi yang telah dihasilkan, PMI asal NTB memiliki kontribusi besar bagi pembangunan di Provinsi Sementara menurut Kepala Badan Pusat Statistik (BPS) Provinsi NTB, Suntono, (Lombok Post, 4 Mei 2020), total uang yang terkirim dari para pekerja migran atau remitansi buruh migran NTB di berbagai negara tahun 2019 lalu sebesar Rp 1,22 triliun. Sementara remitansi yang masuk ke NTB hingga semester I tahun 2020 sejumlah Rp 90,22 milliar, jumlah yang cukup besar yang dapat membantu perputaran roda perekonomian serta pembangunan di Provinsi NTB. Remitansi yang cukup besar tersebut apabila dikelola dengan baik akan dapat menjadi pengerak ekonomi baik dalam skala mikro (keluwarga) maupun skala makro atau wilayah/daerah. Hal ini berarti remitansi harus dijadikan investasi bukan untuk konsumsi. Untuk dapat mewujudkan hal tersebut maka harus ada upaya/ikhtiar dari berbagai pihak yang terlibat untuk memastikan remitansi dikelola secara produktif bukan untuk halhal yang bersifat konsumtif. Tulisan ini bertujuan untuk mengungkap atau mengetahui pengelolaan/tata kelola remintansi buruh migran di kabupaten Lombok Timur Nusa Tenggara Barat.

\section{KAJIAN PUSTAKA}

\section{Pengertian Remitan dan Buruh Migran}

Dalam kamus ekonomi Inggris-Indonesia karangan T. Guritno diterangkan bahwa remitan mempunyai arti pengiriman uang, cek atau wesel. Istilah remitan semula dimaksudkan sebagai uang yang dikirimkan ke desa selama pelaku mobilitas tidak berada di desa (Hugodalam Saefullah, 1994:2). Kemudian, definisi remitan diperluas termasuk transfer dan pertukaran uang dan barang, hadiah, sumbangan, pelayanan, serta distribusi keuntungan dan pembayaran komersial (Curson dalam Saefullah, 1994:2). Sedangkan menurut Mantra dan 37 Kasai dalam Saefullah, 1994:2, remitan adalah pengiriman uang dan barang dari migran atau mover kepada anggota rumah tangga, saudara ataupun masyarakat di daerah asal. Sedangkan buruh migran menurut Natalis Pigay dalam bukunya Migrasi Tenaga Kerja Internasional ditulis sebagai Tenaga Kerja Indonesia (TKI) yang bermigrasi secara internasional akibat globalisasi pada sumber daya manusia. Dalam konteks lain, buruh migran adalah tenaga kerja yang bermigrasi dan mengalami suatu perubahan tempat 
tinggal, baik permanen maupun semi permanen, baik legal maupun ilegal yang menyeberangi batas suatu negara. Pengertian ini mengesampingkan kelompok wisatawan dan komunitas diplomatik yang tidak berkaitan langsung dengan aktivitas ekonomi produksi (Samuel dalam Haris, 2002:11). Menurut Suharto (2005:35), pekerja migran (migrant workers) adalah orang yang bermigrasi dari wilayah kelahirannya ke tempat lain dan kemudian bekerja di tempat yang baru tersebut dalam jangka waktu relative menetap, pekerja migran internasional tidak dapat dipisahkan dari globalisasi. Dalam hal ini tidak dibicarakan pekerja migran internal (dalam negeri) yang bermigrasi dari tempat asalnya untuk bekerja di tempat lain yang masih termasuk dalam wilayah Indonesia. Dari pengertian-pengertian di atas dapat ditarik kesimpulan bahwa remitan buruh migran adalah kiriman (pengiriman) uang, dalam bentuk cek atau wesel hasil dari upah kerja di negara lain dalam kaitannya dengan aktivitas 38 ekonomi produksi yang dilakukan oleh pekerja migran dalam hubungannya dengan daerah asalnya.

\section{Peranan Remitansi Buruh Migran}

Peranan remitan dalam meningkatkan pendapatan keluarga dan kehidupan ekonomi desa telah dibuktikan oleh berbagai penelitian, antara lain Naim, Hugo, Saefullah, Mantra dan Kasai, Mantra dkk, dan Hetler. Berdasarkan hasil penelitiannya di Jawa Barat, Hugo dalam Saefullah (1996:3) melaporkan bahwa lebih dari $83 \%$ responden menyatakan: Keluarga pelaku migran lebih kaya dibanding keluarga bukan pelaku migran. Menurut laporan Naim (1973:4), para migran dari Sumatera Utara tidak hanya mengirimkan remitan kepada keluarga mereka tetapi juga membuat asosiasi (paguyuban) di daerah-daerah tujuan untuk kemudian mengirimkan dana kepada desa-desa mereka untuk pembangunan desa setempat.

Studi migrasi internasional menempatkan remitan sebagai indikator dominan keberhasilan bermigrasi yang dapat dilihat secara langsung. Perspektif ekonomi selalu menjadi hal pokok dalam diskusi dampak pengiriman buruh migran. Analisis lebih banyak mengarah pada mekanisme pengiriman remitan, jumlah, pemanfaatan, dan implementasinya bagi pembangunan wilayah. Bahkan ketika mengkaji pemberdayaan, selalu proksi ekonomi lebih dikedepankan. Hal ini memang tidak dapat disalahkan karena memang motivasi ke luar negeri untuk mendapatkan kehidupan ekonomi yang lebih baik (better standard of living). 
Selama ini jarang yang mengkaji dampak pengiriman buruh migran dari sisi sosial dan kependudukan.

Perlu memang dipertanyakan, mengapa selama ini remitan masih menjadi idola. Jawabnya sederhana, karena remitan memang berhubungan langsung dengan ekonomi rumah tangga migran. Selain itu, pada tingkat makro remitan berperan dalam pembangunan ekonomi regional. Berkenaan dengan arti penting remitan terhadap pembangunan, setidaknya terdapat beberapa alasan yang patut dikaji. Pertama, pada dasawarsa terakhir ini telah terjadi penurunan aliran modal atau investasi dari negara maju ke negara berkembang sebagai akibat krisis ekonomi global (Chimhowu, et al., 2005 disitasi Pitoyo dan Kiswanto, 2012). Penurunan investasi tersebut ternyata justru diikuti dengan peningkatan total remitan yang diterima oleh negara berkembang. Perbandingan remitan terhadap total investasi dalam negeri (private capital inflows) pun cukup tinggi yaitu 43 persen. Hasil studi yang dilakukan oleh Bank Dunia menunjukkan bahwa remitan memegang peranan yang sangat menentukan terhadap stabilitas ekonomi saat di banyak negara Asia terkena krisis ekonomi sekitar tahun 1998 (World Bank, 2002).
Kajian tentang remitansi pada umumnya berada di ranah kajian ekonomi, baik makro maupun mikro, di mana remitansi dihubungkan dengan pembangunan ekonomi, GDP, atau kemampuan ekonomi individunya. Tahun 90an misalnya adalah era di mana kajian tentang remitansi berfokus pada bagaimana remitansi membentuk pembangunan di negara pengirim migran seiring dengan meningkatnyadengan cukup signifikan jumlah remitansi. Pada era ini muncullah apa yang dikenal dengan The New Economics of Labour Migration (NELM). Salah satu artikel yang menganalisa potensi pembangunan dari remitansi dengan menggunakan perspektif NELM ini adalah artikel dari E.J. Taylor. Artikel ini menggunakan contoh-contoh empiris yang menujukkan bahwa remitansi dapat menjadi faktor positif bagi pembangunan ekonomi. Artikel ini menyorot peran sentral pemerintah dalam meningkatkan potensi pembangunan dari remitansi melalui kebijakan ekonomi. Argumentasi ini akan digunakan dalam penelitian ini ketika mengkaji upaya pemerintah dan wewenang kebijakannya.

Di era 2000an, kajian tentang remitansi buruh migran mulai berkembang dengan mencakup aspek-aspek yang lebih luas dan mendetail dari kajian ekonomi dan mulai 
memperhatikan dimensi-dimensi sosial dari remitansi. Buku yang diedit oleh Lan Anh Hoang dan Brenda S.A. Yeoh misalnya merupakan salah satu contoh pengelompokkan kajian tentang remitansi. Buku ini melihat remitansi sebagai proses yang sangat ditentukan oleh aspek gender, generasi dan erat kaitannya dengan krisis keluarga. Artikel-artikel dalam buku ini akan sangat berguna dalam memahami tindakan-tindakan yang dilakukan oleh aktor-aktor individual dalam penelitian ini. Penelitian ini bertitik tolak pada kajian aktor atau actor analysis. Kajian aktor ini banyak digunakan dalam kajian kebijakan, baik dalam maupun luar negeri. Kendala yang dialami penelitian ini adalah aliran dana yang melintasi batas negara dan melibatkan aktor-aktor yang berasal dan berada di negara yang berbeda, maka tidak mudah membuat pembedaan yang tegas antara kebijakan dalam dan luar negeri. Juga disadari bahwa tidak semua upaya menyasar dan mempengaruhi langsung pembuatan dan pelaksanaan kebijakan. Sehingga aktor yang dimaksud tidak diidentifikasi spesifik sebagai aktor kebijakan (policy actors). Karena itu kerangka yang digunakan lebih mengarah pada kerangka tata kelola global: serangkaian aktivitas, peraturan, serta mekanisme berjenjang yang bersifat formal dan informal, publik ataupun privat, yang ada saat ini. Melalui tata kelola global, kerja sama pengaturan danaktivitas antara aktor negara dan aktor-aktor lainnya diharapkan dapat menyelesaikan sejumlah persoalan.

\section{Determinan Buruh Migran}

Sejarah migrasi sangat boleh jadi setua peradaban manusia itu sendiri. Hal ini sejalan dengan hakekat manusia sebagai homo homini socio (makhluk sosial) yang selalu membangun interaksi dengan dunia luar untuk mempertahankan eksistensinya. Indonesia sendiri memiliki catatan panjang mengenai sejarah migrasi dan mobilitas penduduk. Dalam beberapa literatur, di sebutkan bahwa migrasi orangorang Indonesia ke luar negeri mulai dilakukan pada masa pemerintah Hindia Belanda melalui penempatan buruh kontrak ke beberpa negara seperti Suriname dan Afrika Selatan yang juga merupakan wilayah jajahan Belanda. Total penempatan orang Indonesia ke kedua wilayah yang disebutkan mencapai 32.986 orang dengan menggunakan kapal laut dalam beberapa gelombang.

Gelombang pertama pengiriman TKI diberangkatkan dari Batavia dengan menggunakan Kapal "SS Koningin Emma" pada tanggal 21 Mei 1890 menuju Suriname dan tiba pada 9 Agustus 1890 
sebanyak 94 orang terdiri dari 61 pria dewasa dan 31 perempuan, termasuk membawa 2 anak-anak yang dipekerjakan pada perkebunan tebu dan pabrik gula "Marienbung" Suriname.

Gelombang kedua memberangkatkan 582 dengan tujuan yang sama dan tiba tanggal 16 Juni 1894 dengan menggunakan Kapal "SS Vorwaarts". Keberangkatan tahap kedua ini tidak semulus tahap pertama. Karena penumpang yang diangkut over kapasistas dan menyebabkan 64 orang meninggal dunia serta 85 orang dirawat di rumah sakit saat tiba di pelabuhan Paramaribo Suriname. Kejadian ini tidak mendapat tanggapan dari pemerintah Kerajaan Hindia Belanda dan begitu saja diluapakan tanpa ada pertanggung jawaban. Meski demkian pengiriman pekerja migran Indonesia terus berlangsung untuk waktu yang lama hingga 13 Desember 1939 merupakan pemberangkatan terakhir dengan mengirim 990 orang ke tujuan yang sama yakni Suriname.

Pengiriman pekerja migran ke Suriname waktu itu didominasi oleh orang Jawa karena rendahnya tingkat perekonomian penduduk Jawa pasca meletusnya Gunung Merapi tahun 1872 dan pertimbangan soal kepadatan penduduk di Pulau Jawa. Tidak mengherankan sampai dengan tahun 2004 penduduk Jawa di Suriname menempatai urutan ke 4 dengan jumlah mencapai 71.879 orang $(14,6$ peserta) dari 492.829 jiwa penduduk Suriname.

\section{METODE PENELITIAN}

\section{Strategi dan Sasaran Penelitian}

Penelitian ini sepenuhnya menganalisis data dan informasi dari lapangan langsung (data primer) yang didukung atau diperkuat oleh data-data dari pihak lainnya (data sekunder). Metode penelitian atau pendekatan yang digunakan adalah pendekatan kualitatif deskriftif dengan menerapkan beberapa metode pengambilan data yakni : (i) Observasi/Pengamatan, tujuannya adalah untuk mendapatkan gambaran tentang kondisi umum wilayah penelitian (social setting, physical setting dII) melalui dokumentasi foto/gambar; (ii) Indepth Interview dengan sejumlah key informan yang dipilih secara purposive berdasarkan kebutuhan penelitian; (iii) Focus Group Discussion (Kelompok Diskusi Terfokus) dengan peserta 8-10 orang selama 1 kali kegiatan. Partisipannya berasal dari keluarga/RT yang dipilih secara purposive sesuai dengan karakteristik lokasi penelitian. Untuk mendukung analisa terhadap data-data primer, kajian ini juga dilengkapi dengan desk study berupa 
review terhadap data dan informasi sekunder baik berupa laporan-laporan sebelumnya (laporan penelitian, laporan program) maupun data statistik (Monografi Desa, Kabupaten Dalam Angka, Kecamatan Dalam Angka).

Sasaran dari kegiatan penelitian ini adalah informan kunci maupun para partisipan mewakili unsur-unsur: indepth interview (SKPD bidang Kependudukan di Kabupaten; Kepala Desa; Kepala Dusun; Tokoh Masyarakat, LSM dan Keluarga/Rumah Tangga); FGD (Individu yang pernah menjadi buruh migran dan/atau anggota keluarga buruh migran).

\section{Waktu dan Lokasi Penelitian}

Penelitian ini dilaksanakan selama 3 (tiga) bulan efektif sejak pengumpulan data hingga penyusunan laporan akhir dengan mengambil lokasi di Desa Suralaga Kecamatan Suralaga Lombok Timur. Pemilihan dan penetapan lokasi penelitian ini dilakukan secara purposive dengan pertimbangan metodologisnya : pertama, merupakan daerah asal migran yang mampu menjelaskan fenomena migrasi tenaga kerja baik laki-laki maupun perempuan; kedua, memiliki jumlah pekerja migran mencukupi sehingga dapat menggambarkan isu remitan yang dikaji secara representative dan merupakan kantong pekerja migran (pool of migrant workers) dan saat ini masih intensif terjadi pengiriman pekerja ke luar negeri; ketiga, memiliki pengalaman panjang sebagai daerah pengirim migran internasional dengan variasi negara tujuan sehingga berimplikasi pada dinamika remitan berikut perannya dalam kehidupan rumah tangga.

\section{PEMBAHASAN}

\section{Quo Vadis Pengiriman Buruh Migran}

Tingginya pengangguran adalah salah satu alasan munculnya kebijakan pemerintah tentang pengiriman tenaga kerja ke luar negeri. Semenjak tahun 1970-an pemerintah Indonesia telah membuka diri dengan mengirimkan buruh migran ke luar negeri melalui program Angkatan Kerja Antar Negara. Program ini secara operasional dikelola oleh Departemen Tenaga Kerja dan Transmigrasi (Depnakertrans) dengan mengusung tiga tujuan pokok yaitu memperkecil resiko pengangguran, meningkatkan pendapatan, dan sekaligus memberikan peluang lebih besar untuk membangun daerah asal. Pada tingkat individu dan rumah tangga diharapkan dengan bekerja di luar negeri maka akan tercipta peningkatan standar kehidupan ekonomi dan perubahan sosial secara mendasar ke arah lebih baik. Secara makro dalam kerangka kebijakan pembangunan 
nasional program pengiriman tenaga kerja ke luar negeri juga memberikan peluang devisa yang tinggi (Pitoyo dan Kiswanto, 2012).

Pengiriman pekerja ke luar negeri yang tumbuh subur semenjak terjadinya "booming" minyak sekitar tahun tujuh puluhan merupakan awal sejarah proses pengiriman tenaga kerja Indonesia hingga dewasa ini. Kebijakan pengiriman pekerja tersebut belakangan banyak menimbulkan persoalan. Hal ini disebabkan kebijakan tersebut tidak diikuti oleh kualitas kontrol manajemen yang memadai dari pihakpihak pengambil keputusan ditingkat atas. Longgarnya kontrol terhadap aktivitas pengiriman jasa tenaga kerja yang dilakukan oleh pihak-pihak pengerah jasa tenaga kerja keluar negeri membuka peluang-peluang terjadinya berbagai bentuk eksploitasi yang tidak hanya merugikan pekerja itu sendiri, tetapi lebih jauh sangat merugikan bagi kepentingan nasional pada umumnya.

Teori ekonomi klasik maupun neo-klasik menyebutkan bahwa aktivitas migrasi yang berlangsung dari dan ke suatu daerah dapat dilihat sebagai suatu produk perbedaan tingkat upah antara daerah asal dan daerah tujuan. Besarnya perbedaan tingkat upah, dapat dipandang sebagai salah satu determinan penting dalam keseluruhan proses migrasi yang berlangsung (Todaro, 1995). Tidak dapat dipungkiri bahwa surplus tenaga kerja yang jauh melebihi kemampuan daya dukung pasar juga merupakan aspek yang tidak dapat diabaikan pengaruhnya di dalam seluruh program penempatan tenaga kerja luar negeri. Oleh karena itu, aktivitas penempatan tenaga kerja luar negeri juga dapat dipandang sebagai suatu bentuk mekanisme menekan ketidakseimbangan supply-demand. Dalam terminologi Amstrong dan Taylor (1985) hal tersebut dipandang sebagai pengurangan ketimpangan pertumbuhan antarwilayah. Oleh karena itu, aktivitas penempatan tenaga kerja luar negeri juga dapat dipandang sebagai suatu bentuk mekanisme produksi yang tujuannya untuk meningkatkan pendapatan sebagai konsekuensi pilihan ekonomi rasional dalam pengertian yang lebih luas.

Penganut teori ekonomi klasik mengklaim bahwa kemiskinan adalah awal dari pergerakan penduduk (Kritz, 1992). Perpindahan penduduk adalah suatu proses penyeimbangan sumber daya. Penduduk secara alamiah akan berpindah dari daerah dengan sumber daya rendah (low value of advantage) menuju daerah yang memberikan harapan cerah dari sisi kesempatan ekonomi (high value of 
opportunity). Tidak saja dari sisi sumber daya alam, perbedaan kualitas sumber daya manusia pun dapat menjadi faktor pemicu mobilitas penduduk. Perbedaan struktur demografi antara negara maju dengan negara berkembang misalnya, struktur demografi muda di negara berkembang berdampak pada tingginya angka pengangguran, sementara di negara maju terjadi hal yang sebaliknya. Perbedaan struktur demografi tersebut menjadi pemicu tumbuh suburnya migrasi internasional pekerja selain karena dukungan kemajuan teknologi transportasi dan telekomunikasi. Studi empiris di beberapa negara berkembang menunjukkan betapa faktor ekonomi (baca: kemiskinan) telah menjadi alasan dominan fenomena buruh migrant internasional selama ini (Ozden dan Schiff, 2006 disitasi Pitoyo dan Kiswanto, 2012).

Determinan utama penempatan tenaga kerja ke luar negeri adalah aspek-aspek kontekstual yang seringkali dilihat sebagai daya dorong dan daya tarik (push and pull factors) dan faktor penghalang antara dan faktor individu seperti dikemukakan Lee (1995). Secara teoritis faktor-faktor migrasi tersebut terdiri dari variabel-variabel yang sangat bervariasi. Langkanya kesempatan kerja, rendahnya tingkat upah di daerah asal, rendahnya kemampuan pemerintah daerah dalam menyiapkan lapangan kerja, meningkatnya aksesibilitas wilayah, seperti lancarnya jaringan transportasi dan komunikasi antar daerah, faktor politis seperti birokrasi, dan berbagai program pemerintah (Billsborow, 1984) merupakan variabel-variabel yang penting diperhatikan dalam seluruh proses migrasi internasional pekerja. Tingginya kesempatan kerja dan respons pemerintah negara tujuan merupakan daya tarik positif yang menyebabkan diambilnya kebijakan penempatan tenaga kerja. Adapun besarnya tekanan tenaga kerja lokal yang ditandai dengan tingginya angka pertumbuhan angkatan kerja daerah, tingginya persaingan pasar kerja, dan ketidakstabilan politik dan ekonomi dapat menjadi faktor-faktor negatif yang mendorong berkembangnya aktivitas migran magang ke luar negeri.

\section{Tata Kelola Remitansi Buruh Migran}

Migrant CARE. Migrant CARE merupakan NGO yang mefokuskan kegiatannya kepada isu buruh migran. Migrant CARE menjadi salah satu organisasi yang membantu menangani isu migrasi dengan cara-cara yang lebih intens. Migrant CARE melakukan intervensi di lapangan atau daerah di mana buruh migran memiliki permasalahan tertentu. 
Migrant CARE melihat bahwa terdapat 4 hal yang harus menjadi perhatian dalam upaya perlindungan buruh migran. Pertama, hak informasi calon buruh migran ke luar negeri di tingkat desa. Kedua, mengenai mekanisme pendataan calon buruh migran dan buruh migran yang terintegrasi dalam satu sistem informasi di tingkat desa. Ketiga, berkaitan dengan pengaduan ketika buruh migran mengalami permasalahan. Dan terakhir adalah pendampingan bagi buruh migran, terutama berkaitan dengan tata kelola ekonomi agar buruh migran yang kembali ke Indonesia tidak menggunakan seluruh dana yang diperolehnya di luar negeri hanya untuk kegiatan yang bersifat konsumtif. Migrant CARE menjadikan keempat hal tersebut sebagai instrumen yang diupayakan dan diintegrasikan dengan Peraturan Desa yang diperkuat dengan layanan PPIT (Pusat Pelayanan Informasi Terpadu) di tingkat desa. Hal tersebut diwujudkan melalui program DESBUMI (Desa Buruh Migran) dari Migrant CARE yang merupakan sebuah program yang penting dalam memberdayakan buruh migran dan mengumpulkan data mengenai buruh migran yang ada mulai dari data ekonominya hingga data penempatan buruh migran yang ada di desa. Migrant
CARE mengharapkan bahwa desa bisa menjadi pusat informasi mengenai buruh migran pada tingkat daerah.

Migrant CARE menempatkan posisinya sebagai suppporting system dalam membantu mengatasi permasalahan buruh migran. Migrant CARE mendefinisikan dirinya sendiri sebagai supporting system dalam alur remitansi buruh migran bukan sebagai aktor utama karena mereka menganggap inisiatif dan peran utama itu harus datang dari buruh migrannya sendiri. Migrant CARE di sini akan berperan untuk memfasilitasi dan membantumengarahkan serta mendampingi buruh migran dalam membuat usaha dan mengelola dana remitansinya. Bentuk dukungan yang dilakukan Migrant CARE salah satunya dengan mempromosikan produk-produk yang dihasilkan mantan buruh migran. Migrant CARE membantu memasarkan produk dari komunitas-komunitas buruh migran dengan mendorong untuk membuka booth khusus produk dari para buruh migran di pameran-pameran yang diadakan oleh berbagai pihak termasuk dengan mitra Migrant CARE di pemerintahan. Di samping itu, Migrant CARE melakukan pendampingan kepada komunitas melalui program yang disebut dengan MAMPU. Namun dalam hal 
memberikan keterampilan Migrant CARE tidak terlibat langsung karena memiliki sumber daya manusia yang terbatas.

Oleh karenanya, keterhubungan antara berbagai komunitas dan kelompok buruh migran bisa menjadi potensi untuk memberdayakan para buruh migran yang memerlukan pelatihan keterampilan tertentu untuk belajar dari buruh migran lain yang sukses dan berhasil menjalankan usahanya. Karena posisi Migrant CARE yang bersifat sebagai supporting system, Migrant CARE memiliki peluang besar untuk menghubungkan antara komunitaskomunitas buruh migran yang sedang membutuhkan (baik itu membutuhkan ketrampilan, dana, atau konsultasi) dengan pemerintah ataupun pihak-pihak lain yang bisa membantu. Di saat yang sama, kelompok-kelompok usaha para buruh migran yang berada pada tingkat desa memiliki potensi besar terutama ketika benar-benar didampingi dan dilatih untuk melakukan berbagai macam usaha. Selain itu, kelompok yang sudah berhasil dapat membagikan pengalamannya kepada kelompok yang lain sebagai usaha untuk memotivasi dan memberikan pelajaran mengenai memulai usaha.

Berkaitan dengan kendala sumber daya, Migrant CARE aktif melakukan kemitraan dengan berbagai komunitas di berbagai daerah terutama untuk mendorong pemanfaatan potensi di lingkungan mantan buruh migran agar menjadi sumber ekonomi di komunitas daerahnya. Migrant CARE menjadi salahsatu jembatan penghubungan bagi komunitas buruh migran dengan instansi pemerintah terutama dalam hal pameran produk yang dihasilkan buruh migran. Hal tersebut dilakukan untuk mengatasi keterbatasan pemasaran hasil usaha mantan buruh migran yang seringkali menyebabkan usaha mereka tidak bisa berlanjut.

Salah satu tantangan lainnya adalah orientasi kelompok buruh migran yang masih terpusat pada aspek ekonomi dan belum mengangkat isu fundamental seperti identifikasi hak-hak yang dimiliki buruh migran serta bagaimana posisi mereka sebagai perempuan. Oleh karenanya, NGO Nasional ini juga menyasar pada kebijakan-kebijakan pemerintah agar kebijakan yang dibuat lebih berpihak kepada perlindungan buruh migran, seperti UU No. 39 tahun 2004. Migrant CARE menggunakan pendekatan atau cara memberikan masukan dalam bentuk naskah akademik dan saran pasalpasal untuk menggantikan pasal yang berpotensi merugikan buruh migran.

Pada jalur remitansi Migrant CARE melakukan pengawasan terhadap jasa-jasa 
seperti penukaran uang dengan tujuan agar tidak merugikan buruh migran. Tantangan yang dihadapi Migrant CARE khususnya dalam tata kelola remitansi adalah data yang masih mengacu pada BI. Sementara remitansi dilakukan melalui agen seperti Western Union, Pos dan bank lainnya. Migrant CARE melihat bahwa jalur remitansi lewat teman menjadi salah satu permasalahan yang tidak dapat dengan mudah dikendalikan. Selain itu, Migrant CARE melihat bahwa eksistensi buruh migran di komunitas juga sulit dipertahankan. Nilai remitansi yang besar berpotensi menyebabkan tingkat konsumsi yang tinggi, akibatnya dana hasil remitansi habis dipakai untuk membangun rumah atau menyekolahkan anaknya sebelum sempat digunakan untuk usaha tertentu sehingga hal tersebut memaksa dirinya untuk bekerja kembali menjadi TKI. Oleh karenanya, buruh migran cenderung memilih untuk bekerja lagi ke luar negeri dari pada bertahan dalam satu komunitas. Hal tersebut menyebabkan data jumlah remitansi menjadi tidak tercatat dengan baik, sehingga bagi Migrant CARE akurasi data remitansi menjadi sulit untuk ditentukan. Motivasi yang menyebabkan Migrant CARE untuk terlibat dalam tatakelola remitansi adalah agar buruh migran dapat memaksimalkan upah yang dihasilkan dari bekerja ke luar negeri untuk hal-hal yang sifatnya produktif. Salah satu pencapaian bagi Migrant CARE dalam tata kelola remitansi adalah melakukan pendampingan dan membuat mantan buruh migran bertahan di dalam komunitas dan buruh migran untuk melakukan usaha dengan remitansi yang diperoleh di dalam komunitas.

Selain itu dalam wawancara migrant CARE sangat menekankan kepada payung hukum bagi para buruh migran terutama dalam perlindungan hak-haknya dan penyadaran kepada para buruh migran akan hal apa saja yang menjadi haknya. Migrant CARE sebagai NGO Nasional yang mengerti mengenai kebutuhan buruh migran membantu memberi masukkan dalam pembuatan peraturan dalam tingkat nasional dan juga daerah mengenai buruh migran terutama tentang perlindungan kepada buruh migran.

\section{Komunitas Buruh Migran Dan Remitansi}

Melalui wawancara singkat dengan beberapa anggota komunitas buruh migran di desa Suralaga, masalah yang cukup pelik bagi buruh migran adalah pemilihan institusi yang menyampaikan remitansi mereka terhadap sanak mereka di kampung halaman, terutama disebabkan karena biaya pengiriman yang cukup mahal di Hong Kong, Singapura dan 
beberapa negara lainnya, meskipun sudah ada cabang beberapa bank Indonesia di beberapa negara tempat buruh migran bekerja yang seharusnya dapat mempermudah akses pengiriman dana mereka. Seharusnya, pemerintah mengambil peranan lebih besar dalam mempermudah pengiriman remitansi dengan menekan biaya pengiriman karena pada dasarnya biaya pengiriman dana remitansi sangat variatif dan terkadang justru memberatkan para TKI. Idealnya pemerintah membuat perjanjian dengan bank-bank yang sudah memiliki akses terhadap buruh migran di negara penempatan.

Di sisi lain, para buruh migran yang sudah bekerja di luar negeri lalu kembali lagi atau yang biasa disebut TKI Purna, merasa bahwa posisi mereka di masyarakat dan keluarga menjadi lebih diakui dan lebih dipandang karena sudah memiliki pengalaman yang lebih banyak. Tetapi hal tersebut tidak berlaku dalam struktur rumah tangga terutama sebagai istri, karena posisi mereka lebih beragam, ada yang dianggap tetap sama saja atau tidak berpengaruh, tetapi ada juga yang menjadi lebih dianggap oleh suaminya. Mereka juga sepakat bahwa kepergian mereka ke berbagai negara sebagai TKI memberikan banyak pengalaman, yang seharusnya dapat lebih dimanfaatkan, baik oleh diri mereka mereka sendiri ataupun pihakpihak lainnya.

Sejumlah tantangan pun mereka hadapi berkaitan dengan remitansi yang mereka dapatkan selama bekerja di beberapa negara. Pertama, agen-agen perusahaan penghubung TKI tidak memiliki transparansi mengenai biaya yang akan dipotong dari total gaji TKI karena menggunakan agen tersebut. Dengan kata lain, biaya yang ditetapkan jumlahnya tidak tetap dan berbeda-beda karena perusahaan tersebut tidak mau menjelaskan peraturannya. Kedua, hasil remitansi buruh migran yang dijadikan usahasangat sedikit karena pada akhirnya usahanyapun tidak berhasil karena modal yang habis dan usaha yang tidak berkembang atau tidak menghasilkan. Ketiga, buruh migran yang mempunyai keinginan untuk mendirikan usaha dan tidak kembali bekerja sebagai TKI menghadapi kenyataan bahwa usaha yang dibuat tidak dapat bertahan lama karena kendala dalam kemampuan pemasaran dan manajemen yang buruk. Terakhir, pelatihan yang diadakan oleh BNP2TKI tidak bersifat menyeluruh terutama dalam hal wirausaha. Misalnya, tidak ada pelatihan keterampilan manajemen, 
pemasaran, kemasan produk, serta cara meningkatkan nilai jual sebuah produk.

\section{Kelembagaan Pemerintah Dan Remitansi}

Badan Nasional Penempatan dan Perlindungan Tenaga Kerja Indonesia (BNP2TKI) yang kemudian berganti nama menjadi Badan Pelindungan Pekerja Migran Indonesia (BP2MI) merupakan badan yang secara spesifik mengurus berbagai macam isu dan permasalahan buruh migran yang secara resmi dibentuk pada tahun 2008. Menurut BNP2TKI, secara khusus terdapat empat jenis pengiriman remitansi namun yang paling populer sekarang adalah melalui Western Union dan Pos Indonesia, yang juga memiliki kelemahan antara lain, potensi terjadi kehilangan atau tidak sampai ke tujuan tepat waktu dalam proses pengiriman uang dan barang.

Pihak BNP2TKI lebih menganjurkan pengiriman uang dilakukan melalui bank, baik Bank Indonesia maupun bank swasta lainnya, karena lebih aman dan keseluruhan proses transaksinya terdokumentasi dengan baik. Hal ini juga akan mempermudah pencatatan data remitansi bagi negara. Selain itu, BNP2TKI memiliki program pemberdayaan buruh migran terintegrasi dalam bentuk edukasi keuangan tentang cara menabung dan berinvestasi ditambah dengan penyuluhan kewirausahaan agar buruh migran tidak selalu bergantung pada pekerjaan di luar negeri tetapi juga memiliki pemasukan yang stabil di kampung halaman. Program edukasi keuangan yang diselenggarakan BNP2TKI seringkali bekerja sama dengan OJK dan BRI, BNI, Mandiri, Maybank serta Sinarmas. Sementara untuk sejumlah program yang menjurus ke penyuluhan kewirausahaan BNP2TKI bekerja sama dengan LKM lokal maupun berbagai mitra yang berlokasi di daerah pelayanan setempat.

Di samping itu, BNP2TKI memiliki program 0-5 sesuai dengan renstra yang mereka miliki dengan target capaian di tahun 2019. Fokus program ini adalah pada peningkatan TKI formal dan pemberdayaan TKI purna, sehingga untuk calon-calon TKI informal kurang diperhatikan dalam peningkatan keterampilannya. Catatan kritis atas program ini adalah belum bersifat berkelanjutan serta belum memiliki fokus terhadap sejumlah masalah sosial yang berkaitan dengan upaya pengembangan kewirausahaan dari para TKI Purna.

Beberapa hambatan dihadapi oleh BNP2TKI dalam menjalankan program ini antara lain kesadaran dari para buruh migran yang cenderung konsumtif ketika baru saja menerima pendapatan dan 
belum terpikirkan oleh mereka untuk menabung apalagi berwirausaha. Beberapa buruh migran bahkan masih mengalami permasalahan karena tuna aksara, tidak memiliki literasi keuangan dan finansial bahkan ada yang takut untuk pergi ke bank. Proses untuk mengubah pola pikir para buruh migran tersebut membutuhkan waktu yang lama. Permasalahan tersebut dicoba untuk diatasi oleh BNP2TKI dengan cara menghadirkan kunjungan ke institusi perbankan dan mengajak para buruh migran bertemu dengan teller, satpam dan berbagai karyawan bank agar mereka terbiasa dengan kegiatan di bank dan mengetahui mekanisme kerjanya.

Selain itu,BNP2TKI menyelenggarakan program edukasi keuangan dalam bentuk Pembekalan AkhirPemberangkatan yang diadakan ketika para buruh migran akan berangkat menjadi tenaga kerja sementara untuk mengakses daerah pedalaman. Dalam hal ini, BNP2TKI bekerja sama dengan institusi perbankan mengirimkan beberapa mobil perbankan yang sudah mulai mencoba menjangkau ke daerah terpencil, namun hal ini belum efektif karena waktunya yang hanya sebentar, jarak yang jauh, serta infrastruktur yang belum memadai. Di sisi lain, dalam usaha pemberdayaan kewirausahaan, pemerintah membuka empat sektor: pertanian, jasa, ekonomi kreatif dan pariwisata. Permasalahan internal yang dihadapi oleh BNP2TKI sendiri saat menjalankan kegiatan ini adalah kurangnya persebaran BNP2TKI sehingga terdapat kesulitan dalam menjangkau daerah-daerah pedalaman, ditambah lagi dengan kebutuhan berkoordinasi dengan dinas lain yang jauh lebih rumit apabila menyangkut TKI informal.

\section{KESIMPULAN DAN SARAN}

\section{Kesimpulan}

Dari uraian di atas dapat disimpulkan poinpoin berikut. Pertama, untuk pengiriman remitansi, buruh migran masih cenderung mencari cara yang paling sederhana dan aman, serta biaya paling murah. Oleh karenanya, untuk perlindungan proses pengiriman perlu dilakukan oleh lembagalembaga jasa pengiriman uang. Meskipun beberapa pihak bank terkait telah berusaha untuk memberikan pelayanan di negara-negara penerima, namun nampaknya masih belum menjadi pilihan yang popular bagi buruh migran Indonesia. Kedua, penggunaan remitansi masih lebih banyak dipergunakan untuk kebutuhan konsumsi. Untuk itu perlu dilakukan literasi keuangan bagi para buruh migran sehingga mereka dapat mengalokasikan 
remitansinya untuk ditabung atau dijadikan modal usaha. Perencanaan ini perlu dilakukan bahkan sebelum keberangkatan untuk bekerja ke luar negeri. Beberapa lembaga keuangan, lembaga pemerintah dan NGO telah berusaha melakukan upaya literasi keuangan ini namun masih belum sepenuhnya dapat dikatakan berhasil.

Ketiga, diperlukan capacity building untuk memberikan kemampuan bagi BMI untuk memulai usaha dengan modal yang didapat dari remitansi. Dalam praktiknya, pelatihan keterampilan diberikan oleh berbagai institusi, namun tidak banyak yang berhasil mengembangkan dan mempertahankan usaha tersebut. Salah satu tantangan bagi upaya memulai wirausaha ini adalah pemasaran, yang belum tersentuh oleh banyak pihak.

Keempat, khusus untuk buruh migran perempuan, pengiriman dan penggunaan remitansi masih sangat dipengaruhi oleh budaya patriarki yang berlaku di dalam struktur rumah tangga mereka. Status mereka di hadapan suami mereka menjadi faktor penentu bagi keberlangsungan dan pemanfaatan remitansi serta keputusankeputusan yang berkaitan dengan hal tersebut.

\section{Saran}

Penelitian ini telah berhasil mengidentifikasi dan mengklasifikasikan sejumlah aktor yang telah melakukan berbagai upaya untuk meningkatkan pengelolaan remitansi buruh migran Indonesia. Hasil dari penelitian ini semakin mengarahkan pada asumsi bahwa karena remitansi lebih banyak digunakan untuk konsumsi dan bukan untuk memulai usaha, maka bekerja ke luar negeri akan tetap menjadi sumber pendapatan bukan solusi sementara. Tantangan yang harus dihadapi sekarang adalah bagaimana mencari bentuk pengelolaan remitansi yang dapat memungkinkan adanya alternatif lain sumber pendapatan setelah jangka waktu tertentu, seperti usaha atau bisnis yang dikembangkan sendiri atau berkelompok.

\section{DAFTAR PUSTAKA}

Anonimous, 2020, Remitansi Pekerja Migran Indonesi terbesar berasal dari 5 Negara https://databoks.katadata.co.id/datapublish/2020/09/07, diunduh 12-02- 2021

Dewi, Elisabeth. 2010. Relationships between Women Migrant Workers and Their Children in Indonesia: Feminist Perspectives, Community Values and Motherhood. Victoria University. Melbourne. 
Engle, LB. 2004. The World in Motion: Short Essays on Migration and Gender. Geneva: International Organization for Migration.

Hoang, Lan Anh dan Yeoh, Brenda S.A. 2015. Transnational Labour Migration, Remittances and the Changing Family in Asia. London: Palgrave Macmillan.

Karns dan Mingst. 2010. International Organizations: The Politics and Processes of Global Governance. London: Lynne Rienner Publishers.

Taylor, EJ. 1999. "The New Economics of Labour Migration and the Role of Remittances In the Migration Process"

Yazid, Sylvia dan Dewi, Elisabeth. 2015 "Women on the Steering Wheel: Identifying the Potentials of Women in Improving the Protection of Indonesian Women Migrant Workers" dalam Journal of ASEAN Studies Vol 3, No 2 (2015), hal. 102 - 115. 